global water, carbon and nutrient cycles. In global studies, processes must necessarily be captured in models, and in general, today's global models greatly simplify soil carbon dynamics, sketch out or ignore nitrogen and totally neglect phosphorus, acidity and cations. This study shows the importance of an integrated appraisal of soil dynamics in ecosystem function, and demonstrates the increasing maturity of soil science.

David Schimel is at the National Center

for Atmospheric Research, Boulder,

Colorado 80305, USA.

More from the soil

Tales from the Underground: A Natural History of Subterranean Life

by David W. Wolfe

Perseus, \$26, £18.99

\section{Warfare of a chemical kind}

War and Nature: Fighting Humans
and Insects with Chemicals from
World War I to Silent Spring
by Edmund Russell
Cambridge University Press: 2001.336 pp.
$\mathfrak{E} 35, \$ 55(\mathrm{hbk}), \mathfrak{\{} 12.95, \$ 20(\mathrm{pbk})$
$\ldots$ Alastair Hay

Metaphors are like pictures; they save text. So, when senior politicians refer to members of the al-Qaeda terrorist network as 'mosquitoes in a swamp', for example, we understand the allusion. An image is conjured up in our minds, and our response may be more visceral than cerebral. The use of metaphors about nature has a long pedigree and may have something to do with our historic contact with the land. Shakespeare, in Richard II, has Henry Bolingbroke (a future king) refer to those who wrongly occupy properties of his as: "The caterpillars of the Commonwealth, which I have sworn to weed and pluck away."

Military metaphors have a pedigree too, but their use in agriculture is much more a product of scientific developments in the twentieth century. As Edmund Russell points out in War and Nature, over the past 80 years, insects have come increasingly to be seen as the enemy, and suppliers of insecticides have used government and the press to encourage us to buy their products.

This approach was no more evident in the United States than in wartime, and in 1944 the Bureau of Entomology was urging dairy farmers to wage a "War on Insects". At the same time gardeners, if they saw insects, were ordered by the US Department of Agriculture to "shoot to kill". Even magazines for the home, such as House and Garden, were on side, insisting on an "all-out attack on fifth columnists in the garden".
By the Second World War, the use of such phrases was commonplace and did not jar with readers. The groundwork had been laid well and had started even before the end of the previous world war. As Russell points out in his book - which largely describes practice in the United States between 1917 and 1963 - towards the end of the First World War, thoughts were on future disarmament, and chemical munitions were high on the list of candidates. Those employed to make chemicals for war could see unemployment looming.

The fight by the US Chemical Warfare Service (CWS) to survive in a postwar era is well known by those who research this area. Arguments used by the agency and some of its leaders that chemical weapons were more humane than conventional munitions have become fokelore. Analysis of the ratio of deaths to acute injuries certainly showed that chemical weapons caused far fewer fatalities than did bullets or explosives. Data on more chronic injuries were rarely referred to.

Proponents of chemical warfare also argued for even more toxic agents to be developed, so that their use could be threatened in future wars as a deterrent to an enemy. Today, it is not just the toxicity of modern chemical munitions, but their potential to cause significant civilian casualties, that is (hopefully) leading to their demise.

But it was not the development of more toxic chemical-warfare agents that helped the CWS to remain intact. The service's survival was due in large measure to some lateral thinking. Armed with the technology to disperse chemicals, all it needed was a new enemy. Step forward the boll-weevil. Long the bane of those who grew cotton, the bollweevil could at that time only be controlled by the insecticide calcium arsenate. The CWS offered to find a better alternative.

Russell notes that in 1926, after a twoyear research programme, alternatives were found, but none was more efficient than the arsenate. Although the outcome was not a success, press reports began increasingly to eulogize the research skills of the CWS. Government appropriations continued to flow to the agency, and collaboration with civilian government agencies and commercial firms followed. Survival of the CWS was assured by this approach and, apart from a later change of name to the Chemical Corps, the modus operandi of those involved with chemical warfare in the United States has remained the same.

Russell includes incendiaries as chemicalwarfare agents. Germane though they are to his story about the CWS, the inclusion of incendiaries inflates the importance of chemical warfare in the Second World War. Chemical agents today are defined by their toxicity and their mode of action as chemicals that harm life, rather than their flammable properties. The CWS helped to devise

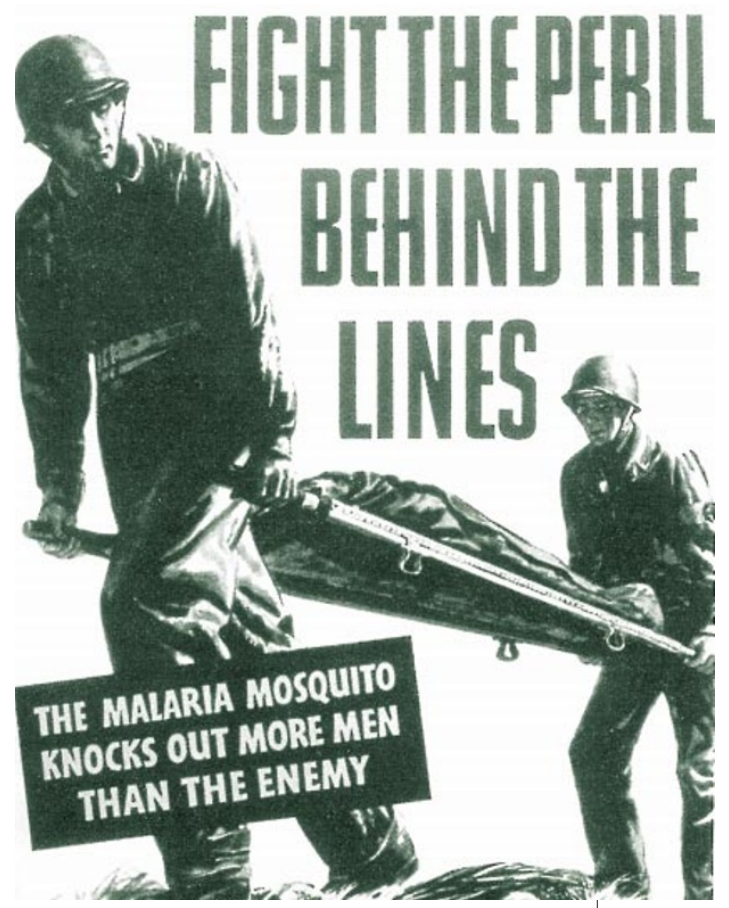

Airborne enemy: the malaria mosquito plagued troops in the Pacific in the Second World War.

and make many of the incendiaries used on Germany and Japan in the Second World War, causing great loss of life. Horrific beyond imagining, these deaths were due to the consequences of the fires and not to direct chemical poisoning.

Russell provides many examples of the interaction between industry and the military and its importance, such as the campaign to spray the insecticide DDT in the Pacific theatre during the Second World War to control the malaria mosquito then besieging US troops. Malaria caused five times as many casualties as military action.

Japanese troops and mosquitoes were juxtaposed in these campaigns, where the emphasis, both in pictures and text, was on elimination of the enemy. This, and other instances of the use of controlling chemicals, provides Russell with ample fodder for a thought-provoking and eminently readable book. A sequel might be about where much of it went wrong.

Alastair Hay is in the Molecular Epidemiology Unit, School of Medicine, University of Leeds, Leeds LS2 9JT, UK.

\section{More on biological warfare \\ Britain and Biological Warfare: Expert Advice and Science Policy, 1930-65 by Brian Balmer \\ Palgrave, $£ 45$, \$75}

\section{Chemical and Biological Warfare: A Comprehensive Survey for the} Concerned Citizen

by Eric Croddy, with Clarisa Perez-Armendariz \& John Hart

Copernicus, \$27.50, £17 